\title{
Nutrition in neuro-intensive care and outcomes
}

\section{Prasanna U. Bidkar}

\section{INTRODUCTION}

The aim of nutrition is to supply nutritional needs of the critically ill patients. The patients who are seriously ill are prone to malnutrition owing to nausea, vomiting, dysphagia, poor mentation and mechanical ventilation. Patients with the head injury, stroke, brain tumours, acute spinal cord injury, and neurologic and neuromuscular disorders are the typical group of patients admitted to Neuro-Intensive Care Units (ICUs). These patients often require non-enteral nutrition owing to dysphagia, poor neurological status and mechanical ventilation. These patients are at risk for malnutrition due to hypercatabolism owing to the disease process, reduced oral intake, visceral protein loss and wasting of muscles due to immobility. A good nutrition supplementation can improve immunity, morbidity and mortality and length of hospital stay. ${ }^{[1]}$

Over the past several years, there is increasing emphasis on early nutritional therapy to all critically ill patients. ${ }^{[2,3]}$ Early enteral feeding has been shown to reduce catabolism and reduce complications and hence can reduce the length of hospital stay and morbidity and mortality in critically ill neurological patients. The benefits of early enteral feeding are more when the therapy initiated within $48-72 \mathrm{~h}$ of neurological insult. ${ }^{[3,4]}$ However, many neuro physicians and surgeons hesitate to start early nutrition therapy in these patients. Even the patients with silent abdomen can tolerate low jejunal feeds when initiated as early as $36 \mathrm{~h}$ post-injury ${ }^{[5]}$ However, many questions remain unanswered in neurologically ill patients, due to lack of precise clinical trials.

- Timing of intervention: Early versus delayed initiation of nutritional therapy and their effect on poor outcome and mortality

Department of Anesthesiology and Critical Care, JIPMER, Puducherry, India

\begin{tabular}{|l|l|}
\hline \multicolumn{2}{|c|}{ Access this article online } \\
\hline Quick Response Code: & Website: \\
\hline & www.jnaccjournal.org \\
\cline { 2 - 2 } & \\
& \\
\hline
\end{tabular}

- Enteral versus parenteral nutrition and their effect on poor outcome and mortality

- Enteral nutrition: Jejunal versus gastric feeding and their effect on poor outcome and mortality

- Use of immunomodulating agents and effect on the outcome.

The present article focuses on the nutrition in traumatic brain injury (TBI) patients and its effect on outcomes in Neuro-ICUs and a small note on nutrition in patients with stroke.

\section{EFFECT OF CRITICAL ILLNESS ON DIFFERENT ORGAN SYSTEMS IN THE BODY}

Almost all organs are affected during critical illness. The severity of the organs affected depends on the severity of the disease. The hypercatabolism and subsequent inappropriate nutritional supplementation can rapidly worsen the functioning of different organ systems in the body [Table1].

\section{NUTRITIONAL SCREENING AND ASSESSMENT OF NUTRITIONAL STATUS}

Nutritional screening is the identification of the patient who is at risk of malnutrition based on the available basic data. Many nutritional tools such as malnutrition universal screening tool, nutrition risk index, mini nutritional assessment and subjective global assessment. Any nutritional screening tool can be adopted based on the institution, the infrastructure and available resources. A detailed discussion on these tools is out of the purview of this article and can be found elsewhere in the literature.

At present, there is no universally accepted gold standard for nutritional assessment of TBI patients. For

This is an open access article distributed under the terms of the Creative Commons Attribution-NonCommercial-ShareAlike 3.0 License, which allows others to remix, tweak, and build upon the work non-commercially, as long as the author is credited and the new creations are licensed under the identical terms.

For reprints contact: reprints@medknow.com

How to cite this article: Bidkar PU. Nutrition in neuro - intensive care and outcomes. J Neuroanaesthesiol Crit Care 2016;3:70-6. 
adequate nutritional assessment, assessment of both medical condition of the patient and nutritional status is important. The diagnosis of the illness, comorbidities (coronary artery disease, diabetes, hypertension, etc.,) and assessment of each organ function should be considered. The anthropometric measurements and blood chemistry are used for assessing the nutritional status. The anthropometric measurements such as weight, height and body mass index are difficult to measure most of the times as patients are critically ill. The estimated measurements can also be inaccurate, due to disturbed fluid balance. The biochemical measurements include calculation of nitrogen balance, albumin, haemoglobin, magnesium, phosphorous, transferrin and pre-albumin.

\section{CALCULATION OF CALORIC REQUIREMENT}

The traditionally used Harris-Benedict's equation or weight-based formulas $(25-30 \mathrm{kcal} / \mathrm{kg} /$ day) are used for calculation of basal energy expenditure (BEE). These static formulas may not accurately predict the amount of replacement required considering the dynamic nature of the disease and hypercatabolism in patients with TBI. Repeated measurements of indirect calorimetry can be used for accurately assessing the energy expenditure. An amount of $140 \%$ of BEE is advocated in patients with TBI with the protein replacements of $1-2 \mathrm{~g} / \mathrm{kg} /$ day. Considering the hypercatabolism state in patients with TBI, proteins can constitute $20 \%$ of the energy of the total daily intake.

\section{TYPES OF NUTRITIONAL SUPPORT: ENTERAL AND PARENTERAL NUTRITION}

There are essentially two types of dietary methods available: Enteral and parenteral nutrition. Enteral feeding is considered as the first choice, where a functioning gastrointestinal (GI) tract is a prerequisite. It has been found to reduce GI bacterial translocation and improves the mucosal integrity and enzymatic activity ${ }^{[8]}$ The main contraindications to enteral feeding include complete mechanical bowel obstruction, high draining enterocutaneous fistula $(>500 \mathrm{ml})$ and intolerance to enteral feeding. The parenteral route of nutrition is employed, when there is a failure of enteral feeding or enteral feeding alone is not sufficient to meet all nutritional demands. Table 2 compares the advantages and disadvantages of both types of nutrition.

Table 1: Involvement of various organ systems in critically ill patients ${ }^{[6,7]}$

\begin{tabular}{|c|c|c|}
\hline Organ involvement & Pathophysiology & Manifestation \\
\hline Cardiovascular system & $\begin{array}{l}\text { Depression of cardiac function by cytokines } \\
\text { Increased oxygen requirement } \\
\text { High cardiac output } \\
\text { Reduced systemic vascular resistance }\end{array}$ & $\begin{array}{l}\text { Myocardial injury } \\
\text { Cardiac failure }\end{array}$ \\
\hline $\begin{array}{l}\text { Neurologic } \\
\text { involvement }\end{array}$ & $\begin{array}{l}\text { Altered catecholamines levels } \\
\text { Altered metabolites and amino acid metabolism } \\
\text { Decrease in forebrain b-receptor density }\end{array}$ & $\begin{array}{l}\text { Confusion, agitation } \\
\text { Altered level of consciousness } \\
\text { encephalopathy }\end{array}$ \\
\hline $\begin{array}{l}\text { Gastrointestinal and } \\
\text { hepatobiliary }\end{array}$ & $\begin{array}{l}\text { Reduced endogenous mucosal protection } \\
\text { (due to lack of feeding) } \\
\text { Reduced gastric acid secretion } \\
\text { Release of pro-inflammatory mediators by liver }\end{array}$ & $\begin{array}{l}\text { Gastric (stress) ulcers } \\
\text { Acalculous cholecystitis } \\
\text { Altered liver function (reduced albumin } \\
\text { production and increased production of } \\
\text { acute phase reactants) }\end{array}$ \\
\hline Pulmonary & $\begin{array}{l}\text { Neutrophil migration } \\
\text { Impaired surfactant function } \\
\text { Atelectasis of lung } \\
\text { Ventilator-associated infections }\end{array}$ & $\begin{array}{l}\text { Acute lung injury } \\
\text { Adult respiratory distress syndrome }\end{array}$ \\
\hline Renal & $\begin{array}{l}\text { Changes in renal blood flow (vasoconstrictor } \\
\text { mediated) } \\
\text { Tubular dysfunction (endotoxin-related) }\end{array}$ & Acute kidney injury \\
\hline Fluid and electrolytes & $\begin{array}{l}\text { Deranged electrolyte balance due to increased } \\
\text { extracellular water, reduced intracellular water, } \\
\text { altered excretion of electrolytes by kidneys }\end{array}$ & $\begin{array}{l}\text { All electrolyte imbalance including hypo/ } \\
\text { hypernatremia, hypo/hyperkalaemia } \\
\text { Hypomagnesaemia, hypophosphatemia }\end{array}$ \\
\hline Endocrine & $\begin{array}{l}\text { Increased acute phase } \\
\text { hormones (catecholamines, cortisol, glucagon) } \\
\text { Reduced thyroxine levels }\end{array}$ & $\begin{array}{l}\text { Stress-induced hyperglycaemia } \\
\text { Critical thyroidal illness }\end{array}$ \\
\hline Immunologic & Suppressed cell mediated immunity & Increased risk of infections \\
\hline
\end{tabular}




\section{TIMING OF NUTRITION: EARLY VERSUS DELAYED NUTRITION}

The current trend is to start early nutritional replacement to all critically ill patients. Brain trauma Foundation guidelines recommend attaining full caloric requirement by 7 days. ${ }^{[9]}$ For this, the nutrient replacement needs to be started within $72 \mathrm{~h}$ and gradually increased to achieve the complete caloric requirement. Studies in the past have tried to compare the early versus delayed nutritional replacement and outcomes in patients with TBI [Table 3] ${ }^{[4,10-17]}$ One of the prerequisites for the enteral feeding is the functioning bowel (presence of bowel sounds). In two of these studies, enteral feeding was started even in the absence of bowel sounds and the patients tolerated the enteral feeding well..$^{[12,13]}$ One of the studies demonstrated reduced infective and overall complications with early jejunal/gastric feeding. ${ }^{[13]}$ This study also demonstrated that the patients who were fed early had a higher percentage of energy and nitrogen requirement by the end of 1 week. ${ }^{[13]}$ A Cochrane meta-analysis ${ }^{[18]}$ which included five studies ${ }^{[4,10-14]}$ concluded that there is a trend towards improved outcome and reduced complications with early enteral feeding.

As a part of New York State quality improvement programme, Brain trauma foundation collects data of 22 trauma centres in New York State. ${ }^{[14]}$ The analysis of data collected from 2000 to 2006 revealed that there was $2-4$-fold increased the risk of death in patients who were not fed within $5-7$ days. Every $10 \mathrm{kcal} / \mathrm{kg}$ decrease in caloric intake during the first 5 days was associated with $30-40 \%$ increase in mortality rates. Similarly, the other two trials published recently concluded that early nutrition is associated with better outcomes. ${ }^{[15,16]}$ Chourdakis et al. ${ }^{[17]}$ studied the effect of early versus delayed enteral feeding on endocrine functions of the patients with TBI. The hormonal levels of thyroid stimulating hormone, free $\mathrm{T} 4$ and free $\mathrm{T} 3$ were reduced in patients with delayed enteral feeding. A recent meta-analysis of available studies on nutritional supplementation in patients with TBI included 4 randomised controlled trials ${ }^{[4,10,11,17]}$ and three non-randomised prospective observational trials. ${ }^{[14-16]}$ The pooled data indicated early nutrition is associated with significant reduction in mortality as compared to delayed initiation of nutrition. ${ }^{[19]}$ Furthermore, analysis of 4 trials $^{[10,11,15,16]}$ revealed the risk of poor outcome is significantly decreased with early nutrition. In summary, early feeding is associated with positive nitrogen balance, better hormonal profile, lower risk of infectious complications, with a reduction in mortality and risk of poor outcomes.

\section{METHOD OF FEEDING: ENTERAL VERSUS PARENTERAL NUTRITION}

The neurologically ill patients can be fed via enteral or parenteral route [Table 4]. The enteral nutrition can be
Table 2: Comparison of enteral and parenteral feeding

\begin{tabular}{|c|c|}
\hline Enteral feeding & Parenteral feeding \\
\hline \multicolumn{2}{|l|}{ Through } \\
\hline $\begin{array}{l}\text { Gastric tube } \\
\text { Jejunal tube } \\
\text { PEG catheters }\end{array}$ & $\begin{array}{l}\text { Peripheral intravenous } \\
\text { Central venous catheters }\end{array}$ \\
\hline \multicolumn{2}{|l|}{ Advantages } \\
\hline $\begin{array}{l}\text { Simpler } \\
\text { Cheaper } \\
\text { Fewer complications } \\
\text { Maintains GI mucosal barrier } \\
\text { Stimulates intestinal blood flow } \\
\text { Prevents disuse atrophy } \\
\text { Improved healing } \\
\text { Reduced catabolism of muscles } \\
\text { Avoids TPN-induced } \\
\text { immunosuppression }\end{array}$ & $\begin{array}{l}\text { Simpler } \\
\text { Can be started early } \\
\text { No dependence on } \\
\text { gastric/intestinal } \\
\text { function } \\
\text { Better muscle mass } \\
\text { (ANZICS trial) } \\
\text { Less need for } \\
\text { interruptions }\end{array}$ \\
\hline \multicolumn{2}{|l|}{ Disadvantages } \\
\hline $\begin{array}{l}\text { Nasogastric tube induced } \\
\text { sinusitis } \\
\text { Risk of pneumonia } \\
\text { (microaspirations, vomiting) } \\
\text { Metabolic derangement like } \\
\text { hyperglycaemia, re-feeding } \\
\text { syndrome } \\
\text { Intolerance (large volume } \\
\text { aspirations) }\end{array}$ & $\begin{array}{l}\text { Cather-related } \\
\text { complications - sepsis, } \\
\text { occlusion } \\
\text { Hyperglycaemia } \\
\text { Hypercholesterolemia } \\
\text { (TPN solutions) } \\
\text { Hyperchloremic } \\
\text { metabolic acidosis } \\
\text { Abnormalities in liver } \\
\text { function tests }\end{array}$ \\
\hline
\end{tabular}

provided either via gastric or jejunal routes. Some studies indicate that nitrogen balance is better with early jejunal or parenteral nutrition. ${ }^{[11,12,20]}$ Unfortunately, none of the studies comparing parenteral nutrition with enteral nutrition are large enough to draw a conclusion, about which of the route is better. A recent meta-analysis that included five trials ${ }^{[10,11,20-22]}$ concluded that there is a trend towards improved outcome with early parenteral nutrition. However, no statistical significance was achieved. In summary, both enteral and parenteral nutrition can be used for nutritional supplementation in patients with TBI. More emphasis should be given to nitrogen intake, nitrogen loss due to the hypercatabolism in these groups of patients.

\section{NASOGASTRIC VERSUS NON-NASOGASTRIC FEEDING}

The enteral feeding can be provided through a naso-gastric, naso-pyloric, naso-intestinal or with percutaneous gastrostomy routes [Table 5]. The nasogastric feeding can be associated with more risk of microaspirations, thus increasing the risk of pneumonia. One study showed 
Table 3: Studies with early enteral/parenteral nutrition in patients with traumatic brain injury

\begin{tabular}{|c|c|c|c|c|c|}
\hline Trial (year) & $\begin{array}{l}\text { Number } \\
\text { of patients }\end{array}$ & EN/PN & $\begin{array}{l}\text { Outcome } \\
\text { measures studied }\end{array}$ & Trial design & Trial results/conclusion \\
\hline $\begin{array}{l}\text { Rapp } \\
\text { et al. }(1983)^{[10]}\end{array}$ & 38 & $\begin{array}{l}\text { Early parenteral } \\
\text { versus delayed } \\
\text { enteral }\end{array}$ & $\begin{array}{l}\text { Survival and } \\
\text { functional recovery } \\
\text { at the end of } 1 \text { year }\end{array}$ & $\mathrm{RCT}$ & $\begin{array}{l}\text { Higher survival with early } \\
\text { nutrition, more positive } \\
\text { nitrogen balance and higher } \\
\text { serum albumin levels }\end{array}$ \\
\hline $\begin{array}{l}\text { Young } \\
\text { et al. }(1987)^{[11]}\end{array}$ & 96 & Early TPN/EN & $\begin{array}{l}\text { Effect on } \\
\text { intracranial pressure }\end{array}$ & $\mathrm{RCT}$ & $\begin{array}{l}\text { No effect on intracranial } \\
\text { pressure on both the groups }\end{array}$ \\
\hline $\begin{array}{l}\text { Grahm } \\
\text { et al. }(1989)^{[12]}\end{array}$ & 32 & $\begin{array}{l}\text { Early jejunal versus } \\
\text { conventional feeding }\end{array}$ & $\begin{array}{l}\text { Tolerance of feeds, } \\
\text { risk of infections, } \\
\text { days of ICU } \\
\text { hospitalizations }\end{array}$ & $\begin{array}{l}\text { Prospective } \\
\text { observational trial }\end{array}$ & $\begin{array}{l}\text { Tolerated early jejunal } \\
\text { feeding despite silent } \\
\text { abdomen, reduced infections } \\
\text { and ICU stay }\end{array}$ \\
\hline $\begin{array}{l}\text { Taylor } \\
\text { et al. }(1999)^{[13]}\end{array}$ & 82 & $\begin{array}{l}\text { Early enhanced EN } \\
\text { versus standard EN }\end{array}$ & $\begin{array}{l}\text { Glasgow } \\
\text { outcome scale at } \\
3 \text { and } 6 \text { months, } \\
\text { infective and total } \\
\text { complications }\end{array}$ & $\mathrm{RCT}$ & $\begin{array}{l}\text { No difference in neurologic } \\
\text { outcome in two groups, fewer } \\
\text { infectious complications in } \\
\text { patients with early enhanced } \\
\text { enteral feeding }\end{array}$ \\
\hline $\begin{array}{l}\text { Minard } \\
\text { et al. }(2000)^{[4]}\end{array}$ & 30 & $\begin{array}{l}\text { Early versus delayed } \\
\text { enteral feeding }\end{array}$ & $\begin{array}{l}\text { Comparing length } \\
\text { of hospital stay } \\
\text { and infectious } \\
\text { complications }\end{array}$ & $\mathrm{RCT}$ & $\begin{array}{l}\text { No difference in length of } \\
\text { hospital stays and infectious } \\
\text { complications }\end{array}$ \\
\hline $\begin{array}{l}\text { Härtl } \\
\text { et al. }(2008)^{[14]}\end{array}$ & 797 & $\begin{array}{l}\text { Feeding practices } \\
\text { with adjusted poor } \\
\text { outcomes }\end{array}$ & $\begin{array}{l}\text { Mortality and risk } \\
\text { of poor outcome }\end{array}$ & $\begin{array}{l}\text { Analysis of } \\
\text { prospectively } \\
\text { collected database } \\
\text { of } 22 \text { trauma centres }\end{array}$ & $\begin{array}{l}\text { Patients no fed within } 5 \text { days } \\
\text { had } 2-4 \text { fold increased } \\
\text { likelihood of death }\end{array}$ \\
\hline $\begin{array}{l}\text { Dhandapani } \\
\text { et al. }(2012)^{[15]}\end{array}$ & 67 & $\begin{array}{l}\text { Attaining full } \\
\text { nutrition replacement } \\
\text { by } 3 \text { days, } 4 \text {-7 days } \\
\text { and after } 7 \text { days }\end{array}$ & $\begin{array}{l}\text { Various nutritional } \\
\text { markers }\end{array}$ & $\begin{array}{l}\text { Prospective } \\
\text { observational trial }\end{array}$ & $\begin{array}{l}\text { Favorable outcome in patients } \\
\text { with early nutrition (<3 days) }\end{array}$ \\
\hline $\begin{array}{l}\text { Chiang } \\
\text { et al. }(2012)^{[16]}\end{array}$ & 297 & $\begin{array}{l}\text { Early EN versus } \\
\text { non-enteral controls }\end{array}$ & $\begin{array}{l}\text { Survival at } 1 \text { week } \\
\text { and better outcome } \\
\text { at } 1 \text { month }\end{array}$ & $\begin{array}{l}\text { Multicentre cohort } \\
\text { trial }\end{array}$ & $\begin{array}{l}\text { Better outcome with early } \\
\text { EN, better GCS recovery }\end{array}$ \\
\hline $\begin{array}{l}\text { Chourdakis } \\
\text { et al. }(2012)^{[17]}\end{array}$ & 59 & $\begin{array}{l}\text { Early versus delayed } \\
\text { enteral feeding }\end{array}$ & $\begin{array}{l}\text { Effect on endocrine } \\
\text { functions }\end{array}$ & $\mathrm{RCT}$ & $\begin{array}{l}\text { Decreased levels of TSH, free } \\
\text { T4 and T3 in delayed EN } \\
\text { group }\end{array}$ \\
\hline
\end{tabular}

that early nasojejunal feeding is well-tolerated despite the absence of bowel sounds. ${ }^{[12]}$ The likelihood of incidence of pneumonia can be reduced by feeding via gastrostomy or transpyloric enteral feeding. ${ }^{[23,24]}$ A recently concluded meta-analysis of the available studies concluded small bowel feeding is associated with lower incidence of pneumonia and ventilator-assisted pneumonia. However, there was no difference in the length of ICU stay, the length of hospital stay and mortality in patients with either intestinal or gastric feeding. ${ }^{[25]}$

\section{CONSTITUENTS OF NUTRITION: STANDARD DIET VERSUS IMMUNE ENHANCING DIET}

Immunity enhancing agents such as arginine, glutamine, probiotics and omega 3 fatty acids can be used in addition to the standard diet used for supplementation of nutrition. The results of pooled data from trials using these agents show that used of these agents is associated with lesser risk of infection, reduction in the cytokine levels and inflammatory markers. ${ }^{[26-28]}$

\section{NUTRITION IN PATIENTS WITH STROKE}

The principles of nutrition are essentially same in stroke patients as that of TBI. However, 30-50\% of stroke patients suffer from dysphagia during acute illness. This dysphagia gradually resolves over next 6 months, but still nearly $10 \%$ of patients experiencing persistent dysphagia. ${ }^{[29]}$ Hence, these patients are at increased risk of malnutrition and dehydration due to poor oral intake. Not only this but also the patients are also at risk of infectious complications such as aspiration 
Table 4: Comparison of enteral and parenteral nutrition in patients with severe traumatic brain injury

\begin{tabular}{|c|c|c|c|c|c|}
\hline Trial (year) & $\begin{array}{c}\text { Number } \\
\text { of patients }\end{array}$ & EN/PN & Outcome measures studied & $\begin{array}{l}\text { Trial } \\
\text { design }\end{array}$ & Trial results/conclusion \\
\hline $\begin{array}{l}\text { Rapp } \\
\text { et al. }(1983)^{[10]}\end{array}$ & 38 & $\begin{array}{l}\text { Early parenteral } \\
\text { versus delayed } \\
\text { enteral }\end{array}$ & $\begin{array}{l}\text { survival and functional } \\
\text { recovery at the end of } 1 \text { year }\end{array}$ & $\mathrm{RCT}$ & $\begin{array}{l}\text { Higher survival with early } \\
\text { nutrition, more positive nitrogen } \\
\text { balance and higher serum } \\
\text { albumin levels }\end{array}$ \\
\hline $\begin{array}{l}\text { Hadley } \\
\text { et al. }(1986)^{[20]}\end{array}$ & 45 & $\begin{array}{l}\text { Early parenteral } \\
\text { versus early } \\
\text { enteral }\end{array}$ & $\begin{array}{l}\text { Daily nitrogen intake, nitrogen } \\
\text { loss, albumin levels and } \\
\text { outcome after severe TBI }\end{array}$ & RCT & $\begin{array}{l}\text { TPN group had higher daily } \\
\text { nitrogen intake, less nitrogen } \\
\text { loss and no difference in albumin } \\
\text { levels or patient outcomes }\end{array}$ \\
\hline $\begin{array}{l}\text { Young } \\
\text { et al. }(1987)^{[11]}\end{array}$ & 96 & Early TPN/EN & Effect on intracranial pressure & RCT & $\begin{array}{l}\text { No effect on intracranial pressure } \\
\text { on both the groups }\end{array}$ \\
\hline $\begin{array}{l}\text { Borzotta } \\
\text { et al. }(1994)^{[21]}\end{array}$ & 48 & $\begin{array}{l}\text { Early parenteral } \\
\text { versus early } \\
\text { jejunal feeding }\end{array}$ & $\begin{array}{l}\text { Attaining nutritional goals } \\
\text { through two different routes }\end{array}$ & RCT & $\begin{array}{l}\text { Both routes were equally effective } \\
\text { in achieving nutritional goals }\end{array}$ \\
\hline $\begin{array}{l}\text { Justo Meirelles } \\
\text { and de Aguilar- } \\
\text { Nascimento } \\
(2011)^{[22]}\end{array}$ & 22 & $\begin{array}{l}\text { Parenteral } \\
\text { versus EN }\end{array}$ & $\begin{array}{l}\text { Nitrogen intake, nitrogen } \\
\text { balance, serum glucose level, } \\
\text { acute phase reactants, length } \\
\text { of hospital stay and outcome }\end{array}$ & RCT & $\begin{array}{l}\text { Higher glucose level in parenteral } \\
\text { group, no difference in nitrogen } \\
\text { balance, length of hospital stay } \\
\text { and clinical outcome }\end{array}$ \\
\hline
\end{tabular}

$\mathrm{RCT}=$ Randomised controlled trials, EN = Enteral nutrition, $\mathrm{PN}=$ Parenteral nutrition, $\mathrm{TBI}=$ Traumatic brain injury, $\mathrm{TPN}=$ Total parenteral nutrition

Table 5: Nasogastric versus non-nasogastric feeding

\begin{tabular}{|c|c|c|c|c|c|}
\hline Trial (year) & $\begin{array}{c}\text { Number } \\
\text { of patients }\end{array}$ & EN/PN & $\begin{array}{l}\text { Outcome measures } \\
\text { studied }\end{array}$ & $\begin{array}{l}\text { Trial } \\
\text { design }\end{array}$ & $\begin{array}{l}\text { Trial results/ } \\
\text { conclusion }\end{array}$ \\
\hline $\begin{array}{l}\text { Grahm } \\
\text { et al. }(1989)^{[12]}\end{array}$ & 32 & $\begin{array}{l}\text { Early jejunal versus } \\
\text { conventional feeding }\end{array}$ & $\begin{array}{l}\text { Tolerance of feeds, risk } \\
\text { of infections, days of ICU } \\
\text { hospitalizations }\end{array}$ & $\begin{array}{l}\text { Prospective } \\
\text { observational } \\
\text { trial }\end{array}$ & $\begin{array}{l}\text { Tolerated early jejunal } \\
\text { feeding despite silent } \\
\text { abdomen, reduced } \\
\text { infections and ICU stay }\end{array}$ \\
\hline $\begin{array}{l}\text { Minard } \\
\text { et al. }(2000)^{[4]}\end{array}$ & 30 & $\begin{array}{l}\text { Early nasoenteric } \\
\text { versus delayed } \\
\text { gastric feeding }\end{array}$ & $\begin{array}{l}\text { Comparing length } \\
\text { of hospital stay and } \\
\text { infectious complications }\end{array}$ & RCT & $\begin{array}{l}\text { No difference in length } \\
\text { of hospital stays and } \\
\text { infectious complications }\end{array}$ \\
\hline $\begin{array}{l}\text { Kostadima } \\
\text { et al. }(2005)^{[23]}\end{array}$ & 41 & $\begin{array}{l}\text { Early gastrostomy } \\
\text { versus conventional } \\
\text { nasogastric feeding }\end{array}$ & $\begin{array}{l}\text { To check for infectious } \\
\text { complications like } \\
\text { ventilator-associated } \\
\text { pneumonia }\end{array}$ & RCT & $\begin{array}{l}\text { Lower incidence of } \\
\text { ventilator-associated } \\
\text { pneumonia but no } \\
\text { difference in length of } \\
\text { hospital stay or mortality }\end{array}$ \\
\hline $\begin{array}{l}\text { Acosta-Escribano } \\
\text { et al. }(2010)^{[24]}\end{array}$ & 104 & $\begin{array}{l}\text { Transpyloric versus } \\
\text { gastric feeding }\end{array}$ & $\begin{array}{l}\text { Early ventilator-associated } \\
\text { pneumonia, days of } \\
\text { mechanical ventilation, } \\
\text { length of ICU stay and } \\
\text { hospital stay }\end{array}$ & RCT & $\begin{array}{l}\text { Transpyloric group } \\
\text { had lower incidence of } \\
\text { pneumonia } \\
\text { Nitrogen difference in } \\
\text { other parameters }\end{array}$ \\
\hline
\end{tabular}

$\mathrm{RCT}=$ Randomized controlled trials, ICU = Intensive Care Unit, EN = Enteral nutrition, PN = Parenteral nutrition

pneumonia. ${ }^{[30,31]}$ Hence, the outcome is worse in patients with dysphagia as compared to non-dysphagic stroke patients.

It is necessary to conduct a screening test for dysphagia in all acute stroke patients. The three most commonly performed tests are (1) water swallowing test, ${ }^{[32]}$ (2) multiple consistency test ${ }^{[33]}$ and (3) swallowing provocation test. ${ }^{[34]}$ The low sensitivities or specificities of these tests preclude their routine use as a screening tool in patients with acute stroke. ${ }^{[35]}$ Videofluoroscopic swallowing study (VFSS) and fibreoptic endoscopic evaluation of swallowing (FEES) are used for dysphagia screening. These tests have shown better predictive accuracy compared with the three clinical tests. ${ }^{[35]}$ In VFSS, a non-ionic contrast agent is given to swallow, and all oral, pharyngeal and oesophageal structures can be visualised using fluoroscopy. In FEES, a fibreoptic bronchoscope is passed through the nose near pharynx and direct visualisation of the swallowing can be done. The FEES has advantages as it can be done bed-side, no radiation exposure and saliva of patients can be directly 
visualised. ${ }^{[36]}$ Initially, in the acute stages, dysphagia screening can be done on daily basis and in later stages twice weekly. If dysphagia persists at the time of discharge, then once month evaluation is indicated for next 6 months.

Then incidence of malnutrition ranges from $24 \%$ to $48 \%$ in acute stroke patients. ${ }^{[37]}$ This may be due to reduced oral intake due to dysphagia, poor level of consciousness and varying grades of cognitive dysfunction. Hence, any of the nutritional screening tools (stated earlier in the article) can be used for nutritional screening in these groups of patients. In the acute phases, a nasogastric feeding is beneficial due to the presence of dysphagia or poor Glasgow Coma Scale (GCS). Early tube feeding within 7 days showed a trend towards improved outcomes in stroke patients. ${ }^{[38,39]}$ Patients with poor GCS and on mechanical ventilation may benefit from early tube feeding. There are no trials comparing enteral or parenteral nutrition in these settings. The tube feeding should be initiated as early as possible, once the patient is stabilised. A nasogastric tube is sufficient for tube feeding in most of the patients. However, in patients with anticipated prolonged enteral feeding ( $>28$ days), early feeding can be initiated through gastrostomy tubes. ${ }^{[23]}$ Additional oral intake may be allowed in stroke patients depending on the severity of dysphagia. Parenteral nutrition is indicated when there is a contraindication for enteral nutrition, or the enteral nutrition fails to meet the demand for nutritional supplementation.

\section{CONCLUSION}

Patients with severe TBI and stroke are at risk of malnutrition due to the dysphagia, poor GCS, mechanical ventilation and hypercatabolism. Nutrition supplementation should be initiated as early as possible, and by 5-7 days should attain the full caloric requirement. Enteral or parenteral or combination of both can be considered for nutritional replacement. Intestinal feeding reduced the risk of pneumonia as compared to gastric feeding. Immune-enhancement diet can reduce the infectious complications in these patients.

\section{Financial support and sponsorship}

Nil.

\section{Conflicts of interest}

There are no conflicts of interest.

\section{REFERENCES}

1. Young B, Ott L, Twyman D, Norton J, Rapp R, Tibbs P, et al. The effect of nutritional support on outcome from severe head injury. J Neurosurg 1987;67:668-76.

2. Minard G, Kudsk KA. Is early feeding beneficial? How early is early? New Horiz 1994;2:156-63.

3. Nyswonger GD, Helmchen RH. Early enteral nutrition and length of stay in stroke patients. J Neurosci Nurs 1992;24:220-3.

4. Minard G, Kudsk KA, Melton S, Patton JH, Tolley EA. Early versus delayed feeding with an immune-enhancing diet in patients with severe head injuries. JPEN J Parenter Enteral Nutr 2000;24:145-9.

5. Kirby DF, Clifton GL, Turner H, Marion DW, Barrett J, Gruemer HD. Early enteral nutrition after brain injury by percutaneous endoscopic gastrojejunostomy. JPEN J Parenter Enteral Nutr 1991;15:298-302.

6. Brealey D, Singer M. Multi-organ dysfunction in the critically ill: Effects on different organs. J R Coll Physicians Lond 2000;34:428-31.

7. Tripathy S. Nutrition in the neurocritical care unit. J Neuroanaesth Crit Care 2015;2:88-96.

8. Hillhouse JH, Neiger R. Pregnancy and lactation. In: Gottschlich MM, Fuhrman MP, Hammond KA, Holcombe BJ, Seidner DL, editors. The Science and Practice of Nutrition Support: A Case-Based Core Curriculum. Dubuque, IA: Kendall/Hunt Publishing Company; 2001. p. 302-19.

9. Brain Trauma Foundation; American Association of Neurological Surgeons; Congress of Neurological Surgeons; Joint Section on Neurotrauma and Critical Care, AANS/CNS, Bratton SL, Chestnut RM, Ghajar J, McConnell Hammond FF, et al. Guidelines for the management of severe traumatic brain injury. XII. Nutrition. J Neurotrauma 2007;24 Suppl 1:S77-82.

10. Rapp RP, Young B, Twyman D, Bivins BA, Haack D, Tibbs PA, et al. The favorable effect of early parenteral feeding on survival in head-injured patients. J Neurosurg 1983;58:906-12.

11. Young B, Ott L, Haack D, Twyman D, Combs D, Oexmann JB, et al. Effect of total parenteral nutrition upon intracranial pressure in severe head injury. J Neurosurg 1987;67:76-80.

12. Grahm TW, Zadrozny DB, Harrington T. The benefits of early jejunal hyperalimentation in the head-injured patient. Neurosurgery 1989;25:729-35.

13. Taylor SJ, Fettes SB, Jewkes C, Nelson RJ. Prospective, randomized, controlled trial to determine the effect of early enhanced enteral nutrition on clinical outcome in mechanically ventilated patients suffering head injury. Crit Care Med 1999;27:2525-31.

14. Härtl R, Gerber LM, Ni Q, Ghajar J. Effect of early nutrition on deaths due to severe traumatic brain injury. J Neurosurg 2008;109:50-6.

15. Dhandapani S, Dhandapani M, Agarwal M, Chutani AM, Subbiah V, Sharma BS, et al. The prognostic significance of the timing of total enteral feeding in traumatic brain injury. Surg Neurol Int 2012;3:31.

16. Chiang YH, Chao DP, Chu SF, Lin HW, Huang SY, Yeh YS, et al. Early enteral nutrition and clinical outcomes of severe traumatic brain injury patients in acute stage: A multi-center cohort study. J Neurotrauma 2012;29:75-80.

17. Chourdakis M, Kraus MM, Tzellos T, Sardeli C, Peftoulidou M, Vassilakos D, et al. Effect of early compared with delayed enteral nutrition on endocrine function in patients with traumatic brain injury: An open-labeled randomized trial. JPEN J Parenter Enteral Nutr 2012;36:108-16.

18. Perel P, Yanagawa T, Bunn F, Roberts I, Wentz R, Pierro A. Nutritional support for head-injured patients. Cochrane Database Syst Rev 2006:CD001530.

19. Wang X, Dong Y, Han X, Qi XQ, Huang CG, Hou LJ. Nutritional support for patients sustaining traumatic brain injury: A systematic review and meta-analysis of prospective studies. PLoS One 2013;8:e58838.

20. Hadley MN, Grahm TW, Harrington T, Schiller WR, McDermott MK, Posillico DB. Nutritional support and neurotrauma: A critical review of early nutrition in forty-five 
acute head injury patients. Neurosurgery 1986;19:367-73.

21. Borzotta AP, Pennings J, Papasadero B, Paxton J, Mardesic S, Borzotta R, et al. Enteral versus parenteral nutrition after severe closed head injury. J Trauma 1994;37:459-68.

22. Justo Meirelles CM, de Aguilar-Nascimento JE. Enteral or parenteral nutrition in traumatic brain injury: A prospective randomised trial. Nutr Hosp 2011;26:1120-4.

23. KostadimaE,KaditisAG,AlexopoulosEI,ZakynthinosE,SfyrasD. Early gastrostomy reduces the rate of ventilator-associated pneumonia in stroke or head injury patients. Eur Respir J 2005;26:106-11.

24. Acosta-Escribano J, Fernández-Vivas M, Grau Carmona T, Caturla-Such J, Garcia-Martinez M, Menendez-Mainer A, et al. Gastric versus transpyloric feeding in severe traumatic brain injury: A prospective, randomized trial. Intensive Care Med 2010;36:1532-9.

25. Wang D, Zheng SQ, Chen XC, Jiang SW, Chen HB, etal.Comparisons between small intestinal and gastric feeding in severe traumatic brain injury: A systematic review and meta-analysis of randomized controlled trials. J Neurosurg 2015:1-8.

26. Falcão de Arruda IS, de Aguilar-Nascimento JE. Benefits of early enteral nutrition with glutamine and probiotics in brain injury patients. Clin Sci (Lond) 2004;106:287-92.

27. Briassoulis G, Filippou O, Kanariou M, Papassotiriou I, Hatzis T. Temporal nutritional and inflammatory changes in children with severe head injury fed a regular or an immune-enhancing diet: A randomized, controlled trial. Pediatr Crit Care Med 2006;7:56-62.

28. Khorana J, Rerkasem K, Apichartpiyakul C, Sakonwasun C, Watcharasakslip W, Waniyapong T, et al. Immunonutrition and cytokine response in patients with head injury. J Med Assoc Thai 2009;92:188-94.

29. Mann G, Hankey GJ, Cameron D. Swallowing function after stroke: Prognosis and prognostic factors at 6 months. Stroke 1999;30:744-8.

30. Hilker R, Poetter C, Findeisen N, Sobesky J, Jacobs A, Neveling M, et al. Nosocomial pneumonia after acute stroke:
Implications for neurological intensive care medicine. Stroke 2003;34:975-81.

31. Holas MA, DePippo KL, Reding MJ. Aspiration and relative risk of medical complications following stroke. Arch Neurol 1994;51:1051-3.

32. DePippo KL, Holas MA, Reding MJ. Validation of the 3-oz water swallow test for aspiration following stroke. Arch Neurol 1992;49:1259-61.

33. Trapl M, Enderle P, Nowotny M, Teuschl Y, Matz K, Dachenhausen $\mathrm{A}$, et al. Dysphagia bedside screening for acute-stroke patients: The Gugging Swallowing Screen. Stroke 2007;38:2948-52.

34. Warnecke T, Teismann I, Meimann W, Olenberg S, Zimmermann J, Krämer C, et al. Assessment of aspiration risk in acute ischaemic stroke - Evaluation of the simple swallowing provocation test. J Neurol Neurosurg Psychiatry 2008;79:312-4.

35. Bours GJ, Speyer R, Lemmens J, Limburg M, de Wit R. Bedside screening tests vs. videofluoroscopy or fibreoptic endoscopic evaluation of swallowing to detect dysphagia in patients with neurological disorders: Systematic review. J Adv Nurs 2009;65:477-93.

36. Warnecke T, Teismann I, Oelenberg S, Hamacher C, Ringelstein EB, Schäbitz WR, et al. The safety of fiberoptic endoscopic evaluation of swallowing in acute stroke patients. Stroke 2009;40:482-6.

37. Stratton R, Green CJ, Elia M. Disease-related Malnutrition. An Evidence Based Approach to Treatment. CABI Publishing; 2003.

38. Dennis MS, Lewis SC, Warlow C. Effect of timing and method of enteraltube feeding for dysphagic stroke patients (FOOD): A multicenter randomised controlled trial. Lancet 2005;365:764-72.

39. Dennis M, Lewis S, Cranswick G, Forbes J. FOOD: A multicentre randomized trial evaluating feeding policies in patients admitted to hospital with arecent stroke. Health Technol Assess 2006;10:1-120. 